\title{
Neonatal citrobacter meningitis
}

\author{
C. M. GWYNN^ and R. H. GEORGE \\ From the Birmingham Maternity Hospital, Edgbaston, Birmingham
}

\begin{abstract}
Gwynn, C. M., and George, R. H. (1973). Archives of Disease in Childhood, 48, 455. Neonatal citrobacter meningitis. An epidemic involving 4 babies with neonatal meningitis due to Citrobacter koseri is described. Only 1 of the 4 babies made a full recovery: 2 others survived with severe permanent brain damage after a prolonged illness, and the fourth baby died after a short fulminating infection.
\end{abstract}

The genus Citrobacter has long been recognized as a saprophyte in the alimentary tract of man (Wilson and Miles, 1964), but its role as a pathogen has been questioned. It is frequently cultured together with other organisms in mixed growths from wounds, urines, and sputa from adults, when it is usually an unimportant saprophyte.

We present evidence showing that this organism can be pathogenic, especially in the neonate, so that its potential pathogenicity should be remembered if it is isolated from a neonatal unit.

\section{Case reports}

Case 1. A male weighing $2 \mathrm{~kg}$ was born on 8 September 1971 to a 21-year-old primigravida after a normal but preterm delivery at 33 weeks.

Examination on admission to the Special Care Baby Unit showed a normal premature infant who remained in excellent health for the next 4 days. On the fourth day, 2 hours after a feed, he collapsed with sighing respirations, peripheral circulatory failure, and generalized hypotonia. As the baby was considered to have a septicaemia, treatment was started with penicillin $20 \mathrm{mg}$ / $\mathrm{kg}$ i.m. 8-hourly and kanamycin $7.5 \mathrm{mg} / \mathrm{kg}$ i.m. 8hourly. The infant's condition deteriorated and he died 13 hours later.

Blood cultures showed no growth after 2 days' incubation. CSF was clear but slightly icteric, with red blood cells $290 / \mathrm{mm}^{3}$ and white blood cells $9 / \mathrm{mm}^{3}$. No organisms were seen in the stained smears of centrifuged deposit. After 18 hours incubation cultures grew 3 colonies of what was later identified as Citrobacter koseri.

Necropsy. The contents of the skull were foul smelling. The meninges were congested and there was a very extensive dirty green exudate over the base of the brain.

\footnotetext{
Received 29 September 1972.

^Present address: The Children's Hospital, Ladywood Middleway, Birmingham B16 8ET.
}

The posterior third of the right hemisphere was soft with a greenish-grey discoloration typical of Gramnegative meningoencephalitis.

The brain showed widespread necrosis of the white matter particularly in the posterior part of the right hemisphere. The necrotic area extended almost to the surface of the brain, but a thin rim of cortex survived. Further less developed areas of necrosis were present in the ventricular walls of both hemispheres. The appearances suggested that the necrosis had begun in the ventricular walls and extended towards the cortex. Histologically, the necrotic regions contained distended blood vessels, many filled with small thrombi, and large numbers of Gram-negative bacilli. Some of the vascular sinusoids of the adrenals also contained fibrin plugs.

The Gram-negative bacilli in the CSF were shown by subculture to be Citrobacter koseri. Cultures made from the surface of the necrotic areas of the brain grew the same organism.

Case 2. This infant, born on 14 October 1971, was the plethoric female partner of a feto-fetal transfusion. Cord $\mathrm{Hb} 25.8 \mathrm{~g} / 100 \mathrm{ml}, \mathrm{PCV} 82 \%$. Her twin remained well. The infant progressed normally until the sixth day of life, when she was found in peripheral circulatory failure, with slow sighing respirations. Blood culture gave a heavy growth of Citrobacter koseri.

The CSF was cloudy and contained numerous Gram-negative bacilli; sugar was $2 \mathrm{mg} / 100 \mathrm{ml}$, protein $350 \mathrm{mg} / 100 \mathrm{ml}$, and culture provided a heavy growth of Citrobacter koseri.

Therapy was started with chloramphenicol $8 \mathrm{mg} / \mathrm{kg}$ 6-hourly i.m. and kanamycin $7.5 \mathrm{mg} / \mathrm{kg} 12$-hourly i.m. After deterioration over the first 24 hours of treatment, she gradually improved and was maintained on both antibiotics for 17 days; over this period the blood cultures became sterile but the CSF remained infected with a rising protein (maximum $600 \mathrm{mg} / 100 \mathrm{ml}$ ). Gentamicin was instituted instead of the kanamycin and chloramphenicol in the 17th day of the illness, and a subdural tap was performed. A large amount of pus 
was removed containing vast numbers of Gramnegative bacilli. Gentamicin was injected subdurally.

A total of 17 subdural taps was performed and gentamicin was injected subdurally each time. On one occasion thick pus was obtained through a rather acutely positioned needle, presumably draining a superficial brain abscess.

A ventriculogram 32 days after the onset of the illness showed porencephalic cysts in the left frontal lobe communicating with the left lateral ventricle. A ventricular tap grew Citrobacter koseri in large numbers; the ventricular protein was $2.5 \mathrm{~g} / 100 \mathrm{ml}$. It was only after the insertion of a Rickham's reservoir and daily injections of gentamicin for 2 weeks that the ventricular CSF became sterile and the protein fell to normal.

The child has since developed hydroccphalus and at 6 months the head circumference was $46 \mathrm{~cm}$. Immunoglobulins at 8 weeks of age showed a low value of IgG $(220 \mathrm{mg} / 100 \mathrm{ml})$. Immunoglobulins at 6 months of age were normal.

Case 3. A male was born on 13 February 1972 after a normal delivery. $\mathrm{He}$ was small-for-dates, weighing $1.72 \mathrm{~kg}$ at term; he progressed normally until the 13th day when he became anorexic and irritable.

A lumbar puncture produced CSF which was opalescent and contained 430 white blood cells $/ \mathrm{mm}^{3}$, protein $150 \mathrm{mg} / 100 \mathrm{ml}$, and sugar $6 \mathrm{mg} / 100 \mathrm{ml}$. Culture gave a light growth of Citrobacter koseri. Blood culture was sterile.

He was treated with chloramphenicol $8 \mathrm{mg} / \mathrm{kg} 6$ hourly for 5 days, sulphadiazine $25 \mathrm{mg} / \mathrm{kg} \mathrm{6-hourly}$ for 14 days, and gentamicin $2 \mathrm{mg} / \mathrm{kg} \mathrm{8}$-hourly for 14 days. The CSF became sterile in 72 hours. The child made an uneventful recovery (apart from one short convulsion within the first 24 hours of treatment) and at age 6 months was well with no sequelae to the meningitis.

Case 4. A male weighing $1.82 \mathrm{~kg}$ was born on 3 May 1972 at 32 weeks' gestation by lower segment ceasarean section for placenta praevia, after an apparently normal pregnancy. He was well for 9 days, apart from jaundice, maximum bilirubin $15.1 \mathrm{mg} / 100 \mathrm{ml}$ on the 5 th day which was treated with 48 -hour phototherapy. On the 9th day he became irritable and was observed to twitch on several occasions. Physical examination at this time was normal. A lumbar puncture produced yellow turbid CSF, with protein $350 \mathrm{mg} / 100 \mathrm{ml}$, sugar $68 \mathrm{mg} / 100 \mathrm{ml}$, red blood cells $200 / \mathrm{mm}^{3}$, white blood cells $150 / \mathrm{mm}^{3}$, a few Gram-negative rods; culture grew Citrobacter koseri. Blood culture, throat swab, and stool yielded a moderate growth of Citrobacter koseri. No Citrobacter was isolated from the umbilicus and the urine was sterile.

Treatment was begun with sulphadiazine $25 \mathrm{mg} / \mathrm{kg}$ 6-hourly, chloramphenicol $8 \mathrm{mg} / \mathrm{kg}$ 6-hourly i.m., gentamicin $2 \mathrm{mg} / \mathrm{kg}$ 8-hourly, and phenobarbitone $3 \mathrm{mg} / \mathrm{kg}$ 6-hourly.
The organism was initially sensitive to sulphonamides, but during treatment became resistant, so the sulphadiazine was stopped after $\mathbf{8}$ days and a daily intrathecal injection of gentamicin $2 \mathrm{mg}$ was added instead.

The infant's general condition improved in 24 hours. The first sterile CSF was obtained after 8 days of treatment, and intrathecal injections were stopped. The infant convulsed 48 hours later and transillumination of the skull showed large bilateral subdural collections over the frontal regions.

Bilateral subdural taps at this time obtained $40 \mathrm{ml}$ cloudy fluid, protein $450 \mathrm{mg} / 100 \mathrm{ml}$, sugar $53 \mathrm{mg}$ / $100 \mathrm{ml}$, and a light growth of Citrobacter koseri.

Daily subdural taps were then performed for the next 7 days and $0.5 \mathrm{mg}$ gentamicin was injected bilaterally. These were followed by a further week of subdural taps performed on alternate days and $1 \mathrm{mg}$ gentamicin injected subdurally into each side. During this time the subdural fluid became sterile. A subsequent ventriculogram showed a large number of cavities, some representing dilated ventricles and others extraventricular cavities.

A ventriculolaparostomy tube with a Rickham's reservoir and a Farr-Turner valve was inserted, but the child was markedly motor retarded with a head circumference of $41 \mathrm{~cm}$ at 13 weeks.

\section{Results}

Bacteriological characteristics. The organism isolated from all 4 cases was a member of the Enterobacteriaceae with characteristics shown in Tables 1 and II.

TABLE I

Characteristics of Enterobacteriaceae organism isolated from 4 cases

\begin{tabular}{l|c|c}
\hline \multicolumn{1}{c|}{$\begin{array}{c}\text { 1\% peptone } \\
\text { water sugars }\end{array}$} & $\begin{array}{c}\text { Fermentation reactions } \\
\text { (acid with gas) }\end{array}$ & $\begin{array}{c}\text { Reaction in } \\
\text { Citrobacter } \\
\text { freundii } \\
\text { (dy) }\end{array}$ \\
\cline { 2 - 3 } Glucose & $\begin{array}{c}\text { Acid production first } \\
\text { obsérved (dy) }\end{array}$ & 1 \\
Lactose & 1 & 1 \\
Sucrose & 2 & $\mathrm{~d}$ \\
Maltose & 1 & 1 \\
Mannitol & 1 & 1 \\
Adonitol & 1 & $\mathrm{Neg}$ \\
Dulcitol & 1 & $\mathrm{~d}$ \\
Inositol & $\mathrm{Neg}$ & $\mathrm{Neg}$ \\
\hline
\end{tabular}

Neg, no fermentation; $d$, most strains positive.

The antibiogram of all four strains showed that they were resistant to ampicillin and sensitive to the cephalosporins, chloramphenicol, colomycin, gentamicin, kanamycin, neomycin, streptomycin, sulphonamides, ${ }^{\star}$ compound trimethoxazole, and tretracycline.

^Resistance to sulphonamides developed in Case 4 during treatment. 
TABLE II

Other biochemical tests

\begin{tabular}{|c|c|c|c|}
\hline $\begin{array}{l}\text { Arginine decarboxylation } \\
\text { Lysine decarboxylation } \\
\text { Ornithine decarboxylation } \\
\beta \text {-galactosidase production } \\
\mathrm{H}_{2} \mathrm{~S} \text { production in TSI } \\
\text { Indole production } \\
\text { Urease production } \\
\text { Malonate utilization } \\
\text { Citrate utilization } \\
\text { Gluconate oxidation }\end{array}$ & $\begin{array}{l}\text { +ve } \\
\text {-ve } \\
\text { +ve } \\
\text { +ve } \\
\text { +ve` } \\
\text { +ve } \\
\text {-ve } \\
\text { +ve } \\
\text { +ve } \\
\text {-ve }\end{array}$ & $\begin{array}{l}\text { Methyl red } \\
\text { Voges-Proskauer } \\
\text { Catalase } \\
\text { Oxidase } \\
\text { O-F test } \\
\text { Gelatin liquefaction } \\
\text { Growth in KCN } \\
\text { Growth on MacConkey } \\
\text { Pigmentation of colonies } \\
\text { Motility tests }\end{array}$ & $\begin{array}{l}\text { +ve } \\
\text {-ve } \\
+ \text { ve } \\
\text {-ve } \\
\text { F } \\
\text {-ve } \\
\text {-ve } \\
\text { +ve } \\
\text {-ve } \\
\text { +ve }\end{array}$ \\
\hline
\end{tabular}

* Weak positive.

F, fermentation; + ve, positive test; - ve, negative test; TSI, triple sugar iron; O-F, oxidation-fermentation test.

Epidemiology. When the second case of meningitis due to Citrobacter koseri appeared, an unsuccessful search was made for a source of the infection. Faecal specimens and biliateral aural swabs were examined from all staff working in the unit. These and samples taken from the floor and walls, hand basins, disinfectants, incubators, and other medical equipment did not contain the organism. In addition, sampling of the ventilation system and settle plates within the cubicles proved negative.

The staff were investigated again after the third case was confirmed, and on this occasion umbilical and stool specimens were also collected from all babies within the unit. The organism was isolated from the faeces of one member of staff and 3 babies. The organism was also recovered from the umbilicus of one of these babies.

The organism was shown to be capable of growth in the presence of triple dye and hexachlorophane, both of which were used for umbilical toilet, but was not isolated from the chlorophane skin powder or triple dye used. Chlorhexidine, povidone-iodine, Milton, and Savlon all prevented growth at concentrations normally used. As a result, umbilical toilet has been changed to aqueous chlorhexidine solution.

Oral neomycin for a period of 7 days successfully eradicated the organism from the stools and neomycin powder from the umbilicus of the healthy carrier.

\section{Discussion}

Disease due to Citrobacter freundii has been reported in adults (Stratford, 1970; Barbulescu, 1969) when it has been isolated from the sputum, urine, and wounds; and in a case of subacute bacterial endocarditis it was cultured from the blood. It has also been reported as causing meningitis (Cavalieri and Piacentini, 1968). A nonlactose fermenting Citrobacter has also been described as a cause of meningitis (Shortland-Webb, 1968).

The 4 cases reported here were due to an unusual Citrobacter which produced indole, decarboxylated ornithine, and failed to grow in $\mathrm{KCN}$ broth. Another unpublished case of neontal meningitis due to this same organism has occurred in another hospital in Birmingham (F. A. J. Bridgwater, personal communication, 1972). A variety of names has been suggested for organisms with these characteristics (Report of the Coli-Aerogenes Sub-committee, 1956; Frederiksen, 1970; Young et al., 1971; Booth and MacDonald, 1971). Frederiksen (1970) classified this as Citrobacter koseri and this term seems the most acceptable.

The relative virulence of Citrobacter koseri and Citrobacter freundii is as yet uncertain, but our own studies (R.H.G., unpublished) suggest that both are equally and not infrequently implicated in other infections. In our investigations Citrobacter koseri was an uncommon member of bowel flora, contrasting with Citrobacter freundii which is frequently present (Wilson and Miles, 1964).

It is of interest that in Case 1 there was evidence of some intravascular thrombosis. Whether this occurred before the infection is difficult to ascertain, but the fact that the organism is capable of infecting an apparently normal child is shown by Case 3 .

The organisms we encountered were sensitive in vitro to all the usual antibiotics used in Gramnegative infections, apart from the ampicillin and, in Case 4, the emergence of sulphonamide resistance. This has not been experienced elsewhere (Stratford, 1970).

We are grateful to Dr. D. I. Rushton for the necropsy report on Case 1, to Dr. S. P. Lapage (Central Public Health Laboratory, Colindale) for confirming the identity of our organism, and to Drs. B. S. B. Wood and P. H. W. Rayner for allowing us to study their patients. 
REFBRERCBS

Barbulescu, E. (1969). Genul citrobacter si implicatiile sale in atologia infectioasa. Microbiologia Parazitologia Epidemiologa, 14, 413.

Booth, E. V., and MacDonald, S. (1971). A new group of Enterobacteria, possibly a new Citrobacter species. fournal of Medical Microbiology, 4, 329.

Cavalieri, S., and Piacentini, I. (1968). Sopra un caso di meningite purulenta neonatale da citrobacter. Fracastoro, 61, 37.

Frederiksen, W. (1970). Citrobacter koseri, a new species within the genus Citrobacter. Spisy Pr̈rirodovedecká Fakulta Universita Purkyne Brne, 47, 89.

Report of the Coli-Aerogenes Sub-committee (1956). The nomenclature of coli-aerognes bacteria. Fournal of Applied Bacterio$\log y, 19,108$.
Shortland-Webb, W. R. (1968). Proteus and coliform meningoencephalitis in neonates. Fournal of Clinical Pathology, 21, 422.

Stratford, B. C. (1970). Clinicolaboratory experience with cephalexin. Postgraduate Medical fournal, October, Suppl. 46, 138.

Wilson, G. S., and Miles, A. A. (1964). Principles of Bacteriology and Immunity, Vol. 1, 5th ed., p. 827. Bd. by W. W. C Topley and G. S. Wilson. Arnold, London.

Young, V. M., Kenton, D. M., Hobbs, B. J., and Moody, M. R. (1971). Levinea, a new genus of the family Enterobacteriaceae. International fournal of Systematic Bacteriology, 21, 58.

Correspondence to Dr. R. H. George, Birmingham Maternity Hospital, Edgbaston, Birmingham B15 2TG. 